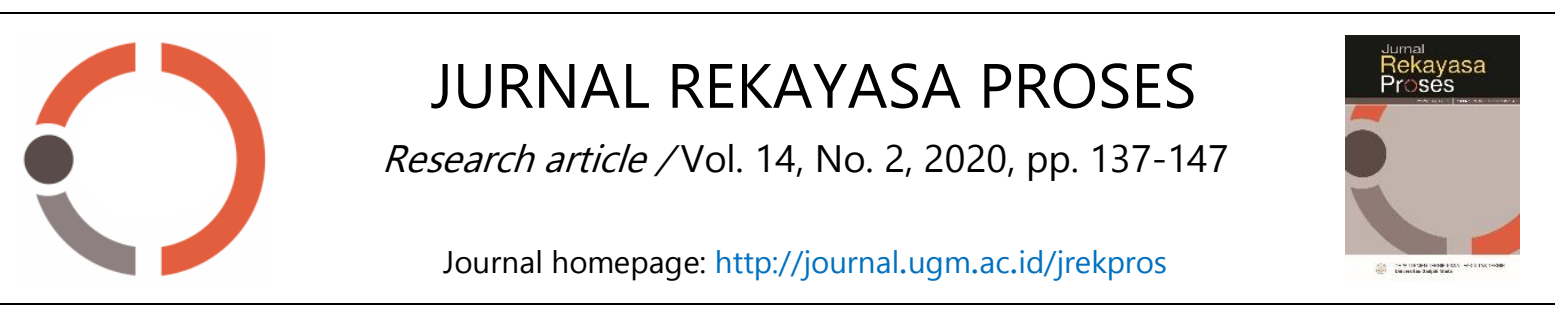

\title{
Biochar from Slow Catalytic Pyrolysis of Spirulina platensis Residue: Effects of Temperature and Silica-Alumina Catalyst on Yield and Characteristics
}

\author{
Siti Jamilatun ${ }^{1 *}$, Ilham Mufandi ${ }^{2}$, Arief Budiman ${ }^{3}$, Suhendra ${ }^{1}$ \\ ${ }^{1}$ Department of Chemical Engineering, Faculty of Industrial Technology, Universitas Ahmad \\ Dahlan, Jalan Kapas 9, Yogyakarta 55166, Indonesia \\ ${ }^{2}$ Department of Mechanical Engineering, Faculty of Engineering, Khon Kaen University, \\ Thailand \\ ${ }^{3}$ Department of Chemical Engineering, Faculty of Engineering, Universitas Gadjah Mada \\ Jalan Grafika No. 2, Kampus UGM, Yogyakarta 55281 \\ *Corresponding author: sitijamilatun@che.uad.ac.id
}

(Submission: 20 May 2020; Revision: 16 August 2020; Acceptance: 1 September 2020)

\section{A B STRACT}

The use of biochar varies on its ability as an adsorbent which adsorbs liquid or gas molecules. Biochar from Spirulina platensis residue (SPR) as an energy source, as its richness in nutrients, can be used as fertilizer and maintain water resources in plantations. Biochar can be used as an intermediary for the synthesis of nanotubes, activated carbon, carbon black, and carbon fiber. One of the essential things to be considered in the application of activated carbon from SPR is char's characteristics. This study aimed to obtain data on the biochar and components from the pyrolysis of Spirulina platensis residue. The study was conducted in a fixed-bed reactor with electric heaters with a variety of temperatures $\left(300-700{ }^{\circ} \mathrm{C}\right.$ ) and the amount of silica-alumina catalyst (0-20\%). The biochar weight was obtained by weighing the char formed at the end of the pyrolysis. The char characteristics were obtained by the surface area, total pore volume, and pore size analysis. Based on the study results, the relationship between temperature and the amount of catalyst on the characteristics of biochar was studied. The higher the pyrolysis temperature, the less biochar. Also, the use of catalysts can reduce the amount of biochar. The higher the temperature, the higher the surface area and the total pore volume while the pore radius was reduced. The optimum condition for maximum biochar yield in non-catalytic pyrolysis at a temperature of $300^{\circ} \mathrm{C}$ was $49.86 \mathrm{wt} . \%$. The surface area, the total pore volume, and the pore radius at $700{ }^{\circ} \mathrm{C}$ catalytic pyrolysis with $5 \%$ silica-alumina was obtained as $36.91 \mathrm{~m}^{2} / \mathrm{g}, 0.052 \mathrm{~cm}^{3} / \mathrm{g}$, and $2.68 \mathrm{~nm}$, respectively.

Keywords: biochar; pore radius; silica-alumina; surface area; total pore volume 
ABSTRAK

Penggunaan biochar bervariasi pada kemampuannya sebagai adsorben dalam menjerap molekul cairan atau gas. Biochar dari residu Spirulina platensis merupakan sumber energi, karena kaya akan unsur hara, dapat digunakan sebagai pupuk dan pemeliharaan sumber daya air di perkebunan. Biochar dapat juga digunakan sebagai perantara untuk sintesis nanotube, karbon aktif, carbon black, dan serat karbon. Salah satu hal penting yang harus diperhatikan dalam aplikasi karbon aktif dari SPR adalah karakteristik arang. Penelitian ini bertujuan untuk mendapatkan data biochar dan komponen dari pirolisis residu Spirulina platensis. Penelitian dilakukan di reaktor fixed-bed dengan pemanas listrik dengan variasi suhu $\left(300-700^{\circ} \mathrm{C}\right.$ ) dan jumlah katalis silika-alumina (0-20\%). Berat biochar diperoleh dengan cara menimbang arang yang terbentuk pada akhir pirolisis. Sedangkan karakteristik arang diperoleh dari analisis luas permukaan, volume pori total, dan ukuran pori. Berdasarkan hasil studi hubungan antara suhu dan jumlah katalis terhadap karakteristik biochar yang telah diteliti, semakin tinggi suhu pirolisis maka biochar semakin sedikit. Selain itu, penggunaan katalis dapat mengurangijumlah biochar. Sebaliknya, semakin tinggi suhu semakin besar luas permukaan, dan volume pori total serta radius pori-pori semakin berkurang. Kondisi optimum untuk biochar maksimum pada pirolisis non katalitik pada suhu $300^{\circ} \mathrm{C}$ adalah 49,86 wt.\%. Luas permukaan, total volume pori, dan radius pori pada suhu $700{ }^{\circ} \mathrm{C}$ untuk pirolisis katalitik silika-alumina 5\% diperoleh masingmasing sebesar $36,91 \mathrm{~m}^{2} / \mathrm{g}, 0,052 \mathrm{~cm}^{3} / \mathrm{g}$, dan 2,68 $\mathrm{nm}$.

Kata kunci: biochar; luas permukaan; radius pori; silika-alumina; total volume pori

\section{Introduction}

Pyrolysis is the most studied thermochemical technology to date and has proven to be one of the best techniques for producing biofuels and biochar from biomass feedstocks (Jamilatun et al., 2019; Li et al., 2016; Tripathi et al., 2016). Biomass sources influence biochar production through pyrolysis, biomass properties (e.g., particle size and moisture content), composition (e.g., cellulose, lignin, and ash content), and process parameters (e.g., temperature, heating rate, residence time) (Yu et al., 2017a). Dickerson and Soria (2013) explained the process parameters for slow pyrolysis; the heating rate is $0.1-1{ }^{\circ} \mathrm{C} / \mathrm{sec}$ with residence time in the range of minutes to hours, and temperatures between $400-600{ }^{\circ} \mathrm{C}$ will produce around 33\% char, 32\% tar, and 35\% gas. The intermediate pyrolysis at $400-500{ }^{\circ} \mathrm{C}$, a heating rate at $1-1000{ }^{\circ} \mathrm{C} / \mathrm{sec}$, hot vapor residence at $10-30$ seconds will produce $25 \%$ char, $50 \%$ tar, and $25 \%$ gas. In contrast, fast pyrolysis can provide $12 \%$ char, $75 \%$ tar, and $13 \%$ gas with a heating rate of 10 to more than $1000{ }^{\circ} \mathrm{C} / \mathrm{sec}$, a residence time of fewer than 2 seconds, and an optimum temperature between $400-650{ }^{\circ} \mathrm{C}$ (Jamilatun et al., 2017; Suganya et al., 2016).

Non-catalytic pyrolysis produces lowquality liquid products with a relatively high oxygenated compound content, which can cause corrosion to the engine. Reduction of oxygenate compounds can improve quality; another way is to use a catalyst during pyrolysis (Jamilatun et al., 2019). One of the catalysts commonly used for cracking hydrocarbons is silica-alumina, the solid acid catalyst most widely used in supporting the production of petrochemicals, chemicals, and renewable energy. High acidity (low Si/Al) can 
be used in the process of cracking petroleum; its function is to increase oxidation of $\mathrm{CO}$ (Wang et al., 2019). The silica-alumina catalyst is suitable for upgrading bio-oil, has a high melting point $\left(1818{ }^{\circ} \mathrm{C}\right)$ and surface area (Cheng et al., 2016; Duan et al., 2013). The catalytic pyrolysis results can improve bio-oil and biochar; it is essential to know the yield and characteristics (surface area, total pore volume, pore radius) of biochar produced in biochar application.

Microalgae is currently a third-generation raw material for biofuel production. It also produces several pharmacologically necessary and nutritious chemicals such as pigments and fatty acids. The simultaneous production of biofuel raw materials and fine chemicals in microalgae biorefinery can improve the economy (Elkhalifa et al., 2019). Biochar from the pyrolysis of microalgae has a lower surface area and carbon content than biochar from lignocellulose. However, biochar has excellent characteristics such as higher $\mathrm{pH}$, its ability to balance soil acidity, and higher nutrient content, including minerals such as nitrogen, ash, and inorganic elements compared to another biomass. Other characteristics of biochar from microalgae such as surface area, total pore volume, and pore radius are still rarely discussed; for this reason, it is necessary to identify with the BET method (Chen et al., 2018; Ido et al., 2019).

Biochar is a solid residue from pyrolysis, formed from primary and secondary pyrolysis reactions, containing carbon and stable elements with high carbon content. The use of biochar varies because of its inert nature and ability to absorb liquid or gas molecules, as a gasification substrate for energy generation. It has excellent potential to be used directly for combustion because it emits much lower $\mathrm{CO}_{2}$ with higher energy than fossil fuels (Lee et al., 2020). Biochar can be used directly as a solid form of biofuel without the complicated extraction process required by liquid-based biofuels. Another advantage of biochar is that the nutrients can be used as fertilizer and to maintain water resources on plantations. As an intermediate material, biochar can be used as a raw material for the synthesis of nanotubes, activated carbon, carbon black, and carbon fiber (Lee et al., 2020).

Biochar with a relatively high surface area can be used as a catalyst and for wastewater treatment. Some biochar from microalgae such as Chlorella sp, Chlamydomonas $s p$, Coelastrum sp, Spirulina platensis has a surface area of $6.163,2.122,15.032$ and 167 $\mathrm{m}^{2} / \mathrm{g}$ with pyrolysis time of $0.5,0.5,0.5$ and 2 hours, respectively (Choi et al., 2020). Wang et al. (2013) reported that the surface area of biochar originating from Chlorella vulgaris $\left(2.4 \mathrm{~m}^{2} / \mathrm{g}\right)$, macroalgae Eucheuma $s p$. has a much higher surface area (30.03-34.82 $\left.\mathrm{m}^{2} / \mathrm{g}\right)$ than other species ranging from 1.29 to 8.87 $\mathrm{m}^{2} / \mathrm{g}$ (Yu et al., 2017b).

Research on the characteristics of biochar from microalgae and their applications is still not widely found, therefore data on pore area, total pore volume, and pore radius is essential to determine the superiority of biochar from microalgae. This paper aims to study the effect of temperature and the amount of silica-alumina catalysts on product yields and product biochar characteristics from the pyrolysis of residual Spirulina platensis (SPR). Biochar characteristics were analyzed by the Brunauer-Emmett-Teller (BET) method and catalysts by the BET method and XRF. The SPR is obtained from solid residue extraction of Spirulina platensis. The study was conducted 
with fixed bed reactors with a variety of temperatures $\left(400-700{ }^{\circ} \mathrm{C}\right)$, and the amount of silica-alumina catalyst (5-20\%). The catalyst was in the form of pellets. Based on the characteristic data obtained, it is expected that there will be a follow-up treatment from biochar so that it can be appropriately utilized.

\section{Research Methodology}

\subsection{Materials}

Dry Spirulina platensis residue (SPR) was obtained from Spirulina platensis (SP) solid residue extraction, while SP was obtained from Nogotirto Algae Park, Yogyakarta, Indonesia. Wet Spirulina platensis residue (SPR) was first sun-dried for three days, then cleaned, and stirred for homogenization. The SPR was stored in a dry and closed place. Then, the SPR was analyzed for the ultimate and proximate content (Jamilatun et al., 2019).

Silica-alumina was obtained in powder form from PT Pertamina Balongan, Indramayu, Indonesia. For applications in pyrolysis, it needs to be formed in the form of pellets. Pellets were created by mixing silicaalumina (95 wt.\%) with kaolin (5 wt.\%). Distilled water was added to the homogeneous mixture and it was formed into pellets of $4 \mathrm{~mm}$ in diameter and $6 \mathrm{~mm}$ high. The catalyst pellet was dried in a furnace at $500^{\circ} \mathrm{C}$ for 2 hours, then cooled in a desiccator.

\subsection{Procedures}

Fifty (50) g SPRs were put into the reactor, then tightly closed, and heated with electricity. Temperature controlled with a $\mathrm{NiCr}-\mathrm{Ni}$ thermocouple placed outside the reactor. Heating was carried out at a heating rate of $5-35{ }^{\circ} \mathrm{C} /$ minute from room temperature $\left(30{ }^{\circ} \mathrm{C}\right)$ to the desired temperature $\left(300-700^{\circ} \mathrm{C}\right)$. Pyrolysis gas was condensed, liquid products coming out of the condenser were collected in the accumulator, and the amount of gas production was measured. Biochar products were obtained after the experiment was completed. The amount of biochar was measured by weighing. The biochar yields were calculated by Equation (1).

\subsection{Instrument and data analysis}

The experiment was carried out in a fixedbed reactor made of stainless steel with the inner diameter of $40 \mathrm{~mm}$, the outer width of $44 \mathrm{~mm}$, and the height of $600 \mathrm{~mm}$, equipped with a heater of nickel wire wrapped around the reactor's outer cylinder (Jamilatun et al., 2019). The pyrolysis system's diagram with the fixed-bed reactor is presented in Figure 1.

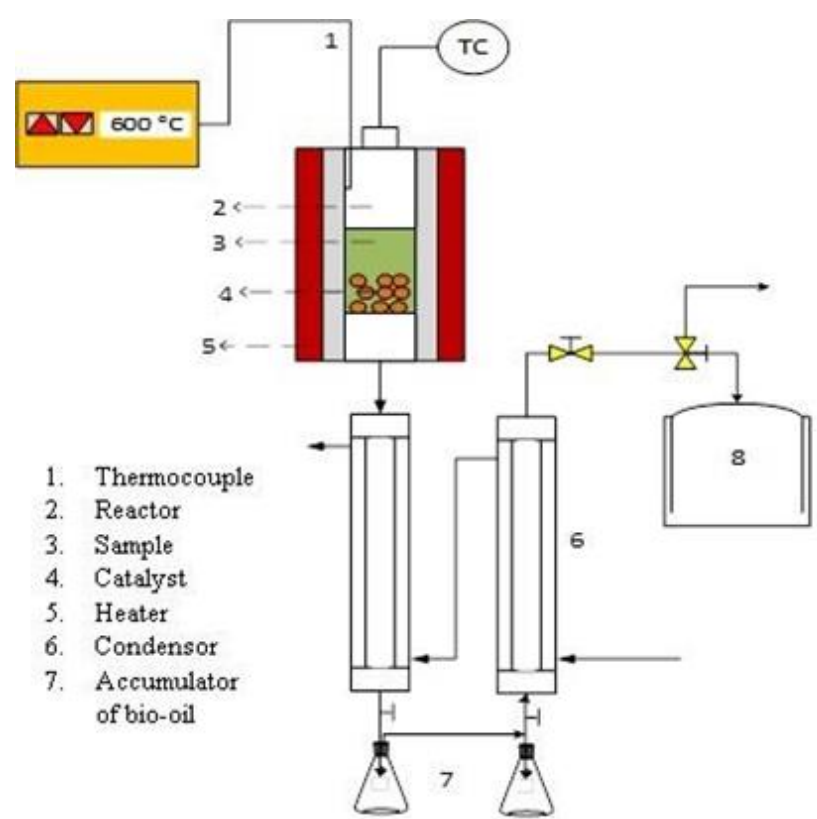

Figure 1. The Pyrolysis system of SPR (Jamilatun et al., 2019)

The reactor is constructed of two cylindrical reactors in vertical series (Reactors 1 and 2). Spirulina platensis residue of $50 \mathrm{~g}$ is put into the top of reactor one and the catalyst to the bottom of the two reactors, 
then tightly closed and heated. The temperature of the reactor was controlled by a NiCr-Ni thermocouple that was placed outside of the reactor. The SPR samples were heated with a heating rate in the range of 5 $35{ }^{\circ} \mathrm{C} / \mathrm{min}$ from $30^{\circ} \mathrm{C}$ to the desired temperature range of $300-700{ }^{\circ} \mathrm{C}$. The condenser unit condensed the pyrolysis gas.

The liquid yield was collected in the accumulator, and the produced gas was measured. After the experiment finished, the remaining solid product (biochar) was taken and weighed. The bio-oil yields were calculated by Equation 1.

\subsubsection{Biochar Yield}

The biochar yield was calculated using Equation (1).

$$
Y_{C}=\frac{W_{C}}{W_{M}} \times 100 \%
$$

In this case, $Y_{C}$ notation is the yield of charcoal products, while $W_{M}$ and $W_{C}$ are the initial SPR weighting and charcoal weight, respectively.

\subsubsection{Sample of Spirulina platensis residue}

Spirulina platensis residue sample analysis included proximate, ultimate, and higher heating value $(\mathrm{HHV})$. Proximate analysis (protein with the Kjeldahl method; carbohydrates with the Anthrone method; lipids with the Soxhlet method) and HHV (Bomb calorimeter) were carried out at the Laboratorium Pangan dan Hasil Pertanian, Departemen Teknologi Pertanian dan Laboratorium Pangan dan Gizi, Pusat Antar Universitas (PAU), UGM Indonesia. The ultimate analysis $(\mathrm{C}, \mathrm{H}, \mathrm{O}, \mathrm{N}$, and $\mathrm{S}$ with a standard $D$ 2361) was conducted at the Laboratorium Pengujian, Puslitbang Tekmira, Bandung Indonesia.

\subsubsection{Silica-Alumina}

Measurement of the surface area, total pore volume, and radius pore were carried out using the BET method (Brunaur, Emmett, and Teller) by Quantachrome NovaWin - Data Acquisition and Reduction NOVA instruments 1994-2013, Quantachrome Instruments version 11.03. The content of $\mathrm{C}, \mathrm{O}, \mathrm{Al}, \mathrm{Si}$, and silica-alumina ratio $\mathrm{SiO}_{2} / \mathrm{Al}_{2} \mathrm{O}_{3}$ with $\mathrm{SEM}$-EDX (Scanning Electron Microscope-Energy Dispersive X-ray), each conducted at the Laboratorium Penelitian dan Pengujian Terpadu (LPPT), UGM. (Jamilatun et al., 2019). The X-ray fluorescence (XRF) analysis was carried out at The International Frontier Division, Dept. Transdisciplinary Science and Technology School of Environmental and Society, Tokyo Institute of Technology, Japan. The XRF microscopy analyzes were carried out at normal atmospheric pressure with currents of $50 \mathrm{kV}$ and $1.0 \mathrm{~mA}$, in the Horiba Scientific XGT-5200 Analytical X-ray Microscope, with high spatial resolution from $1.2 \mathrm{~mm}$ to $10 \mu \mathrm{m}$.

\subsubsection{Biochar Product}

Prior to the adsorption test, biochar was degraded at $150{ }^{\circ} \mathrm{C}$ for 10 hours. The specific surface area of BET ( $\mathrm{S}_{\mathrm{BET}}$ ) was determined by the Brunauer-Emmett-Teller equation (BET). Total pore volume $\left(\mathrm{V}_{\text {total }}\right)$ was established by a single point adsorption total pore volume analysis. The $4 \mathrm{~V} / \mathrm{S}_{\mathrm{BET}}$ determines the average pore diameter (D) based on the BET method (Chen et al., 2018). BET analysis was carried out at the Laboratorium Analisis Instrumental (ANINS), Chemical Engineering Department, UGM by Quantachrome Nova Win-Data Acquisition and Reduction for NOVA instruments 1994-2013, Quantachrome Instruments version 11.03. 


\section{Results and Discussions}

\subsection{Analysis Results}

The SPR sample ultimate analysis revelated the percentage of $\mathrm{C}, \mathrm{H}, \mathrm{N}$, and $\mathrm{O}$ of 41.36 , $6.60,7.17$, and 35.33 wt.\%, respectively. On the other hand, the proximate analysis resulted in the lipids, proteins, and carbohydrates composition of $0.09,49.60$, and $38.51 \mathrm{wt} . \%$, respectively. While the HHV of the SPR is $12.8 \mathrm{MJ} / \mathrm{kg}$.

Silica-alumina was analyzed by Scanning Electron Microscope-Energy Dispersive X-ray (SEM-EDX). The results are shown in Figure 2.

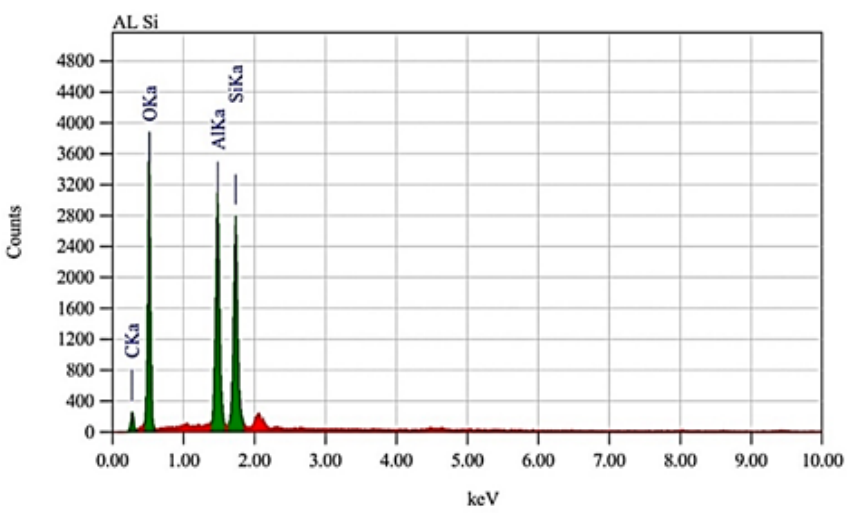

Figure 2. Silica-alumina SEM-EDX results

Figure 2 shows the magnitude of the voltage (keV) used, and each catalyst constituent $(\mathrm{C}, \mathrm{O}, \mathrm{Al}$, and $\mathrm{Si})$. Si obtained at a voltage of $1.739 \mathrm{keV}$ with a complete counting of 2400 counts, while $\mathrm{Al}$ is received at a voltage of $1.486 \mathrm{keV}$ with 6800 counts. Based on the ZAF Standardless Quantitative Analysis Method and using the Fitting Coefficient: 0.0684 , the weight percent values of $\mathrm{C}, \mathrm{O}, \mathrm{Al}$, and Si were 12.33, 55.73, 15.42, and $16.51 \%$, respectively. Meanwhile, from the BET measurement, surface area, average pore volume, and pore diameters were 240.53 $\mathrm{m}^{2} / \mathrm{g}, 0.199 \mathrm{~cm}^{3} / \mathrm{g}$ total pore volume, and 3.3 $\mathrm{nm}$. The XRF analysis results of $\mathrm{SiO}_{2}, \mathrm{Al}_{2} \mathrm{O}_{3}$, and ratio $\mathrm{SiO}_{2} / \mathrm{Al}_{2} \mathrm{O}_{3}$ were 60.28 wt., 35.25 wt., and $1.71 \%$, respectively (Jamilatun et al., 2019).

\subsection{Biochar Yield}

The biochar yield data of pyrolysis with fixed-bed reactors at various temperatures and the amount of silica-alumina is shown in Figure 3

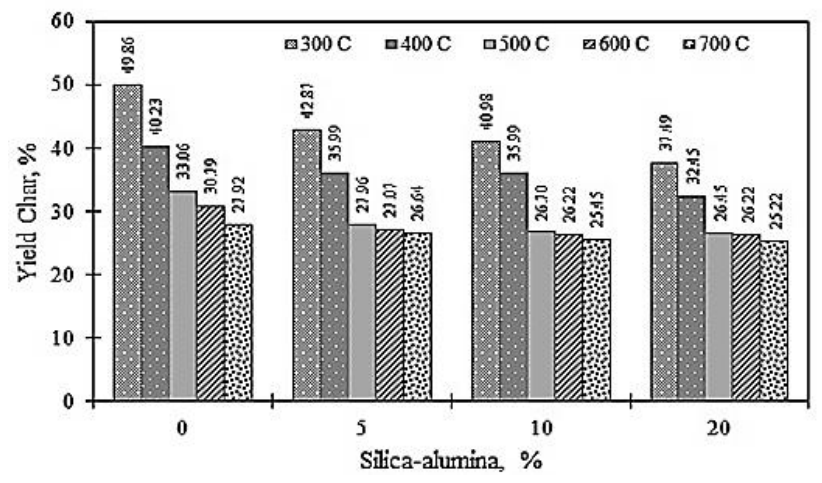

Figure 3. The influence on temperature and amount of catalyst on biochar yield

Based on Figure 3, the pyrolysis temperature rise of non-catalytic and catalytic pyrolysis has a similar trend. The increasing pyrolysis temperature will affect the biochar yield to decrease further. The increase in pyrolysis temperature will reduce the biochar yield. It causes thermal cracking of the heavy hydrocarbon material, leading to an increase in fluids and gases and a decrease in the biochar yield. The primary pyrolysis reaction happens at low temperature, and decomposition occurs gradually to produce charcoal. While at high temperatures, rapid evaporation occurs, which leads to the formation of volatiles. The high temperature causes a secondary pyrolysis reaction. The biochar formed during the primary reaction is decomposed into liquefied and noncondensed gas, reducing the charcoal (Tripathi et al., 2016). In non-catalytic pyrolysis, temperature increases from 300, 
$400,500,600$, and $700{ }^{\circ} \mathrm{C}$ will produce biochar of $49.86,40.23,33.06,30.79$, and $27.92 \%$, respectively.

The addition of silica-alumina to pyrolysis will increase secondary reactions, causing a slight decrease in biochar. In the secondary reaction, the tar will undergo further decomposition into gas to increase the amount of non-condensable gas yield and reduce the amount of condensable-gas and biochar yield. At the temperatures of 300 and $400{ }^{\circ} \mathrm{C}$, the increasing amount of catalyst has little effect on yield decreasing of biochar. Whereas at $500-700{ }^{\circ} \mathrm{C}$, the use of catalysts $(5$, 10 , and $20 \%$ ) had no impact on reducing the charcoal amount. The optimum conditions of pyrolysis to produce high biochar yield is achieved at a temperature of $300{ }^{\circ} \mathrm{C}$ without a catalyst. However, to produce biochar with better characteristics (surface area, total pore volume, and pore radius), a catalyst is recommended.

\subsection{Biochar Surface Area}

The effect of temperature and the amount of silica-alumina on the biochar surface area is shown in Figure 4. Based on Figure 4, the impact of temperature rise for both noncatalytic and catalytic pyrolysis is quite significant on the surface area. As the temperature gets higher, the surface area tends to increase. The optimum condition is obtained at $700{ }^{\circ} \mathrm{C}$ for non-catalytic, the biochar surface area is $23.45 \mathrm{~cm}^{2} / \mathrm{g}$, while for catalytic pyrolysis ( $5 \%$ silica-alumina) the surface area is $36.91 \mathrm{~m}^{2} / \mathrm{g}$. The biochar surface area for the use of $5 \%$ silica-alumina at 400 , 500,600 , and $700{ }^{\circ} \mathrm{C}$ was $3.99,4.18,23.45$, and $36.91 \mathrm{~m}^{2} / \mathrm{g}$, respectively.

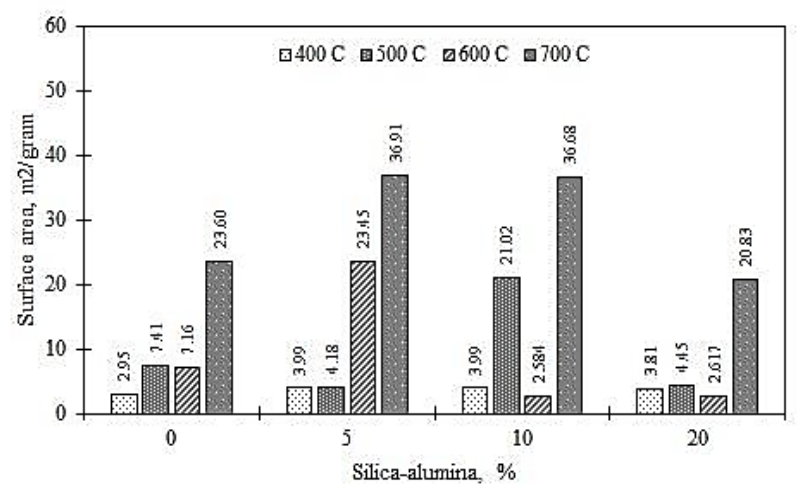

Figure 4. The influence of silica-alumina catalyst on surface area biochar

Microalgae-based biochar appears to be promising in terms of energy potential because of its higher HHV range (14.50-36.67 $\mathrm{MJ} / \mathrm{kg}$ ) and relatively higher surface area (up to $80 \mathrm{~m}^{2} / \mathrm{g}$ ). The content of various functional groups and inorganic elements in biochar is useful in the process of adsorption for environmental control (Lee et al., 2020). Based on the surface area data obtained, it can be interpreted that biochar from microalgae has the potential to be developed into activated charcoal with physical or chemical activation to achieve a larger size of the surface area. The choice of pyrolysis temperature needs to be considered to obtain high biochar yield and surface area. According to Zheng et al. (2017), the pyrolysis of Chlorella $s p$. at a temperature of $600{ }^{\circ} \mathrm{C}$ produces biochar with a surface area of $6.16 \mathrm{~m}^{2} / \mathrm{g}$. Wang et al. (2013) reported that the biochar surface area of $C$. Vulgaris was $2.40 \mathrm{~m}^{2} / \mathrm{g}$, while Roberts et al. (2015) reported on biochar produced from macroalgae Eucheuma sp. has a much higher surface area (30.03-34.82 $\left.\mathrm{m}^{2} / \mathrm{g}\right)$ than other species ranging from 1.29 to $8.87 \mathrm{~m}^{2} / \mathrm{g}$. Compared to this study, the biochar produced by SPR pyrolysis with silica-alumina at the same temperature, namely $600{ }^{\circ} \mathrm{C}$, has a much higher surface area, namely $36.91 \mathrm{~m}^{2} / \mathrm{g}$. 


\subsection{Biochar Total Pore Volume}

The effect of temperature and the amount of silica-alumina on the total pore volume are shown in Figure 5 . The temperature and the amount of catalyst have significant effects on the total pore volume at $700{ }^{\circ} \mathrm{C}$. The optimum total pore volumes were obtained at a temperature of $700{ }^{\circ} \mathrm{C}$ in non-catalytic and catalytic pyrolysis with 5,10 , and $20 \%$ silicaalumina were $0.036,0.052,0.052$, and 0.041 $\mathrm{cm}^{3} / \mathrm{g}$, respectively. The total pore volume data of biochar from microalgae are not published as much as the data for the pore area. However, Chen et al. (2018) report that the pyrolysis of Spirulina platensis at $600{ }^{\circ} \mathrm{C}$ with a barium $(\mathrm{Ba})$ catalyst produces a total pore volume of $0.004 \mathrm{~cm}^{3} / \mathrm{g}$.

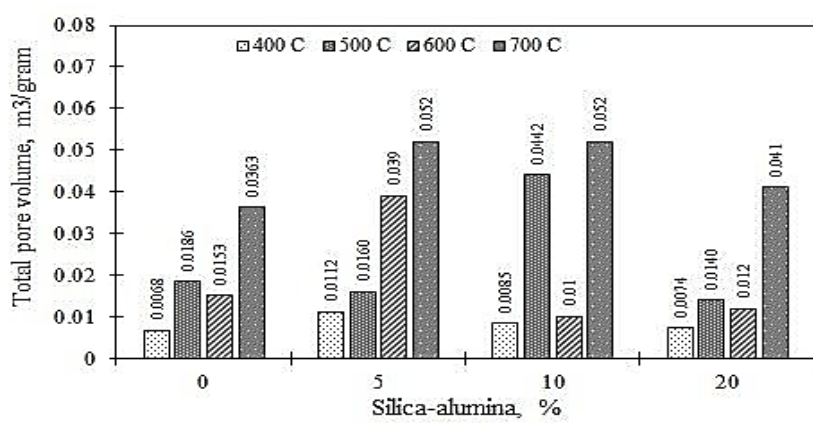

Figure 5. The influence of temperature and the amount of silica-alumina catalyst on total pore volume

\subsection{Biochar Pore Size}

The effect of temperature and the amount of alumina-silica catalyst on the biochar radius can be seen in Figure 6. Based on this figure, the pore radius for temperatures of 300-400 ${ }^{\circ} \mathrm{C}$ from non-catalytic and catalytic pyrolysis has the same trend. The rising temperature will increase the pore radius, but at a temperature of $700{ }^{\circ} \mathrm{C}$, the pore radius drops sharply. The correlation between surface area and pore radius is that the higher temperature increases the surface area; otherwise, the pore radius will decrease (Yu et al., 2017b). The pore radius ranges resulted from $400-700{ }^{\circ} \mathrm{C}$ for non-catalytic and catalytic pyrolysis with $5 \%, 10 \%$, and $20 \%$ silica-alumina were 2.68-2.70, 2.68-2.72, 2.692.71 and $2.68-2.70 \mathrm{~nm}$. The biochar product from non-catalytic and catalytic pyrolysis SPR leads to mesoporous sizes of 2-50 $\mathrm{nm}$. Chen et al. (2018) reported that the biochar product of Spirulina platensis from catalytic pyrolysis with Barium $(\mathrm{Ba})$ has the characteristics of pore area, total pore volume, and pore radius of $0.09 \mathrm{~m}^{2} / \mathrm{g}, 0.04 \mathrm{~m}^{3} / \mathrm{g}$, and $177 \mathrm{~nm}$, respectively.

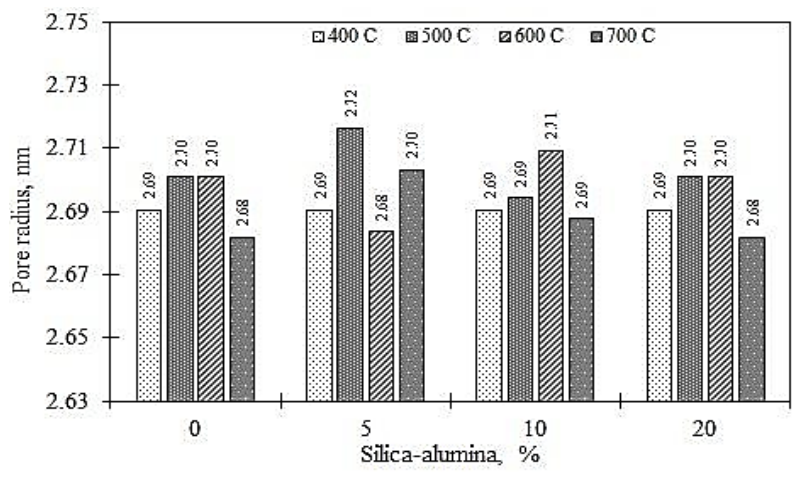

Figure 6. The influence of temperature and the amount of silica-alumina catalyst on pore radius biochar

3.6 Comparison of SPR Biochar Characteristics with the Other Findings

Table 1 compares the process of pyrolysis of different microalgae and the biochar products produced in fixed-bed reactors with slow pyrolysis. The pyrolysis of brown macroalga Laminaria japonica and green macroalgae Cladophora glomerata shows that the higher the pyrolysis temperature, the lower the yield of biochar (Jung et al., 2016), while the surface area is increasing (Bordoloi et al., 2016; Norouzi et al., 2016). Bordoloi et al. (2016) reported that an increase in temperature from $300-600{ }^{\circ} \mathrm{C}$ affected the increase in surface area from 1.72 to $123 \mathrm{~m}^{2} / \mathrm{g}$. 
Table 1. The pyrolysis process and characteristic biochar microalgae (Yu et al., 2017)

\begin{tabular}{|c|c|c|c|c|}
\hline $\begin{array}{c}\text { Pyrolysis } \\
\text { Process }\end{array}$ & $\begin{array}{l}\text { Biomass } \\
\text { feedstock }\end{array}$ & $\begin{array}{c}\text { Temperature } \\
\left({ }^{\circ} \mathrm{C}\right)\end{array}$ & Biochar production & References \\
\hline $\begin{array}{l}\text { Slow } \\
\text { pyrolysis }\end{array}$ & $\begin{array}{l}\text { Brown Laminaria } \\
\text { japonica } \\
\text { macroalgae }\end{array}$ & $200-800$ & $\begin{array}{l}\text { - } \quad 78.34 \% \text { at } 200{ }^{\circ} \mathrm{C} \\
\text { - } \quad 63.64 \% \text { at } 400{ }^{\circ} \mathrm{C} \\
\text { - } \quad 37.96 \% \text { at } 600{ }^{\circ} \mathrm{C} \\
\text { - } \quad 27.05 \% \text { at } 800{ }^{\circ} \mathrm{C}\end{array}$ & $\begin{array}{l}\text { Jung et al. } \\
\text { (2016) }\end{array}$ \\
\hline $\begin{array}{l}\text { Fixed-bed } \\
\text { pyrolysis }\end{array}$ & $\begin{array}{l}\text { Scenedesmus } \\
\text { dimorphus }\end{array}$ & $300-600$ & $\begin{array}{l}\text { Surface area of biochar increased from } 1.72 \text { to } 123 \mathrm{~m}^{2} / \mathrm{g} \text { when } \\
\text { temperature increased from } 300-500{ }^{\circ} \mathrm{C} \text {; reduced to } 89 \mathrm{~m}^{2} / \mathrm{g} \text { at } \\
600^{\circ} \mathrm{C}\end{array}$ & $\begin{array}{l}\text { Bordoloi et } \\
\text { al. (2016) }\end{array}$ \\
\hline $\begin{array}{l}\text { Fixed-bed } \\
\text { pyrolysis }\end{array}$ & $\begin{array}{l}\text { Green } \\
\text { macroalgae } \\
\text { Cladophora } \\
\text { glomerata }\end{array}$ & $400-600$ & $\begin{array}{l}\text { - } \quad 44 \mathrm{wt} \% \text { yield at } 400{ }^{\circ} \mathrm{C} \\
\text { - } \quad 40 \mathrm{wt} \% \text { yield at } 500^{\circ} \mathrm{C} \\
\text { - } \quad 39 \mathrm{wt} \% \text { yield at } 600{ }^{\circ} \mathrm{C}\end{array}$ & $\begin{array}{l}\text { Norouzi et al. } \\
\text { (2016) }\end{array}$ \\
\hline $\begin{array}{l}\text { Fixed-bed } \\
\text { pyrolysis } \\
\text { Slow } \\
\text { pyrolysis }\end{array}$ & $\begin{array}{l}\text { Spirulina } \\
\text { platensis residue }\end{array}$ & $300-700$ & $\begin{array}{l}\text { - Yield biochar at catalyst } 0,5,10 \text { and } 20 \% \text { in the range } \\
27.92-49.86,26.64-42.87,25.45-40.98 \text {, and } 25.22-37.49 \% \text {, } \\
\text { respectively. } \\
\text { - Catalyst } 0,5,10 \text { and } 20 \%\left(700{ }^{\circ} \mathrm{C}\right) \text { surface area of } 31.47 \text {, } \\
36.905,36.667,20.826 \mathrm{~m}^{2} / \mathrm{g}, \text { respectively } \\
\text { - Catalysts with } 0,5,10, \text { and } 20 \%\left(700^{\circ} \mathrm{C}\right) \text { total pore volume } \\
\text { of } 0.036,0.052,0.052 \text { and } 0.041 \mathrm{~cm}^{3} / \mathrm{g} \text {, respectively } \\
\text { - Catalysts with } 0,5,10 \text {, and } 20 \%\left(700^{\circ} \mathrm{C}\right) \text { pore radius of } \\
2.682-2.701,2.684-2.717,2.688-2.709 \text { and } 2.682-2.701 \mathrm{~nm} \text {, } \\
\text { respectively }\end{array}$ & $\begin{array}{l}\text { This } \\
\text { experiment }\end{array}$ \\
\hline
\end{tabular}

The results of non-catalytic and catalytic SPR pyrolysis research at the temperatures of $300-700{ }^{\circ} \mathrm{C}$ with the variations of $0,5,10$, and $20 \%$ alumina-silica catalysts yielded biochar yields in the range of $27.92-49.86,26.64-42.8$, $25.45-40,98$, and $25.22-37.49 \%$, respectively.

Based on the yield of biochar, the optimum conditions in non-catalytic pyrolysis were obtained, at a temperature of $300{ }^{\circ} \mathrm{C}$ with 49.86 wt.\% yield. Based on the characteristics of biochar, the optimum conditions for catalytic pyrolysis was obtained with $5 \%$ silica-alumina catalyst at $700{ }^{\circ} \mathrm{C}$, which resulted in the surface area, total pore volume, and pore radius of $36.91 \mathrm{~m}^{2} / \mathrm{g}, 0.052$ $\mathrm{m}^{3} / \mathrm{g}, 2.68 \mathrm{~nm}$, respectively.

\section{Conclusions}

Non-catalytic pyrolysis produces bio-oil with a high content of oxygenated compounds, so the use of silica-alumina catalysts improves the bio-oil quality. Catalytic pyrolysis will affect the quality of biochar, such as surface area, total pore volume, and pore radius. Non-catalytic and catalytic pyrolysis of Spirulina platensis residue (SPR) was carried out in a fixed bed reactor. The results of pyrolysis at the temperatures of $300,400,500,600$ and $700{ }^{\circ} \mathrm{C}$ with silica-alumina catalyst varied at $0,5,10$ and $20 \%$ were biochar yields in the range of 27.92-49.86, 26.64-42.87, 25.45-40.98 and $25.22-37.49 \%$; the surface area in the range of 2.95-23,60, 3.99-36.91, 3.99-20.83; the total pore volume in the range of $0.007-0.036$, 0.011-0.052, $0.009-0.052$ and 0.007-0.041 $\mathrm{m}^{3} / \mathrm{g}$; and the pore radius in the range of $2.682-2.701,2.684-2.717,2.688-2.709$ and 2.682-2.701 $\mathrm{nm}$, respectively. The optimum condition for producing the maximum 
biochar yield is non-catalytic pyrolysis at the temperature of $300{ }^{\circ} \mathrm{C}$, which is $49.86 \mathrm{wt} . \%$. However, to obtain better biochar characteristics, this condition does not apply. Based on the biochar characteristics, the optimum conditions were obtained at $700{ }^{\circ} \mathrm{C}$ by catalytic pyrolysis with $5 \%$ of silicaalumina, which obtained the surface area, total pore volume, and radius pore as 36.91 $\mathrm{m}^{2} / \mathrm{g}, 0.052 \mathrm{~m}^{3} / \mathrm{g}, 2.68 \mathrm{~nm}$, respectively.

\section{Acknowledgements}

The researcher would like to thank the internal research funding assistance through the Institute of Research and Community Service (LPPM) Ahmad Dahlan University Yogyakarta with a contract number: PD237/SP3/LPPM-UAD/2020.

\section{References}

Bordoloi, N., Narzari, R., Sut, D., Saikia, R., Chutia, R.S., and Kataki, R., 2016, Characterization of bio-oil and its subfractions from pyrolysis of Scenedesmus dimorphus, Renewable Energy, 98, 245253

Chen, W., K., Xia, M., Yang, H., Chen, Y., X., and Che, Q., 2018, Hanping Chen, Catalytic deoxygenation co-pyrolysis of bamboo wastes and microalgae with biochar catalyst, Energy, 157, 472-482.

Cheng, S., Wei, L., Zhao, X. and Julson, J., 2016, application, deactivation, and regeneration of heterogeneous catalysts in bio-oil upgrading, Catalysts, 6, 195.

Choi, Y-K., Choi, T-R., Gurav, R., Bhatia, S.K., Park, Y-L., Kim, H.J., Kan, E., and Yang, Y-H., 2020, Adsorption behavior of tetracycline onto Spirulina sp. (microalgae)-derived biochars produced at different temperatures, Science of the Total Environment, 710, 136-282.

Dickerson, T. and Soria, J., 2013, Catalytic fast pyrolysis: A Review, Energy, 6, 514-538.

Duan, P., Bai, X., Xu, Y., Zhang, A., Wang, F., Zhang, L., and Miao, J., 2013, Catalytic upgrading of crude algal oil using platinum/gamma alumina in supercritical water, Fuel, 109, 225-233.

Elkhalifa, S., Al-Ansari, T., Hamish R. Mackey, and Gordon McKay, 2019, Food waste to biochars through pyrolysis: A review, Resour., Conserv. Recycl., 144, 310-320.

Ido, AL, de Luna, M.D.G., Ong, D.C., and Capareda, S.C., 2019, Upgrading of Scenedesmus obliquus oil to high-quality liquid-phase biofuel by nickelimpregnated biochar catalyst, J. Cleaner Prod., 209, 1052-1060.

Jung, K.-W., Jeong, T.-U., Kang, H.-J., and Ahn, K.-H., 2016, Characteristics of biochar derived from marine macroalgae and fabrication of granular biochar by entrapment in calcium-alginate beads for phosphate removal from aqueous solution, Bioresour. Technol., 211, 108116.

Jamilatun, S., Budhijanto, Rochmadi, and Budiman, A., 2017, Thermal decomposition and kinetic studies of pyrolysis of Spirulina platensis residue, International Journal of Renewable Energy Development, 6(3), 193-201.

Jamilatun, S., Budiman, A., Anggorowati, $H$. Yuliestyan, A., Surya Pradana, Y. Budhijanto, and Rochmadi, 2019, Ex-situ catalytic upgrading of Spirulina platensis residue oil using silica-alumina catalyst, Int. J. Renew. Energy Res., 9 (4), 1733-1740.

Li, J., Dai, J., Liu, G., Zhang, H, Gao, Z., Fu, J., Y., and Huang, Y., 2016, Biochar from 
microwave pyrolysis of biomass: A review, Biomass Bioenergy, 94, 228-244.

Lee, X.J., Ong, H.J., Gan, Y.Y., Chen, W-H., and Mahlia, T.M.I., 2020, State of art review on conventional and advanced pyrolysis of macroalgae $T$ and microalgae for biochar, bio-oil and bio-syngas production, Energy Convers. Manage., 210, 112707.

Norouzi, O., Jafarian, S., Safari, F., Tavasoli, A., and Nejati, B., 2016, Promotion of hydrogen-rich gas and phenolic-rich biooil production from green macroalgae Cladophora glomerata via pyrolysis over its bio-char, Bioresour. Technol., 219, 643651.

Roberts, D.A., Paul, N.A., Bird, Ml, and de Nys, R., 2015, Bioremediation for coal-fired power stations using macroalgae, J. Environ. Manage.,153, 25-32.

Suganya, T, Varman, M., Masjuki, H.H., and Renganathan, S., 2016, Macroalgae and microalgae as a potential source for commercial applications along with biofuels production: A biorefinery approach, Renewable and Sustainable Energy Rev., 55, 909-941, 2016.

Tripathi, M., Sahu, J.N., and Ganesan, P., 2016, effect of process parameters on production of biochar from biomass waste through pyrolysis: A review, Renewable and Sustainable Energy Rev., 55, 467-481.

Wang, K., Brown, R., C., Homsy S., Martinez, L., and Sidhu S., S., 2013, Fast pyrolysis of microalgae remnants in a fluidized bed reactor for bio-oil and biochar production, Bioresour. Technol. 127, 494-499.

Yu, K.L., Show, P.L., Ong, H.C., T.C., Lan, J.C-W., Chen, W.H., and Chang, J-S., 2017a, Microalgae from wastewater treatment to biochar - Feedstock preparation MARK and conversion technologies, Energy Convers. Manage., 150, 1-13.

Yu, KL, BF, P.L., Ong, H.C., TC, W-H., Ng, and EP, J-S., 2017b, Recent developments on algal biochar production and characterization, Bioresour. Technol., 246, 2-11.

Zheng, H., Guo, W., Li, S., Chen, Y., Wu, Q., Feng, X., Yin, R., Ho, S-H., Ren, N., and Chang, J.-S., 2017, adsorption of $p$ nitrophenols (PNP) on microalgal biochar: analysis of high adsorption capacity and mechanism, Bioresour. Technol, 244, 14561464. 